\section{Science Fictions: A Scientific Mystery, a Massive Cover-up, and the Dark Legacy of Robert Gallo}

Crewdson describes in painstaking detail how the dispute developed: from the discovery in Paris in January 1983 by Françoise Barre of a new retrovirus (HIV) cultured from lymphocytes of a French patient, to its resolution in Washington, D.C. in July 1994 with the acknowledgment that the virus isolated at the National Institutes of Health in Gallo's laboratory (HTLV-IIIb) was in fact one of the first viruses isolated in 1983 at the Pasteur Institute. The daily practice of modern science is revealed in these pages-how scientists obtain data in the lab, derive confindings, present at meetings and negotiate with editors and reviewers to get the papers published in the top journals. The book reads like a detective story; it has a protagonist of sorts in Suzanne Hadley, a prominent member of the NIH's Office of Research Integrity,

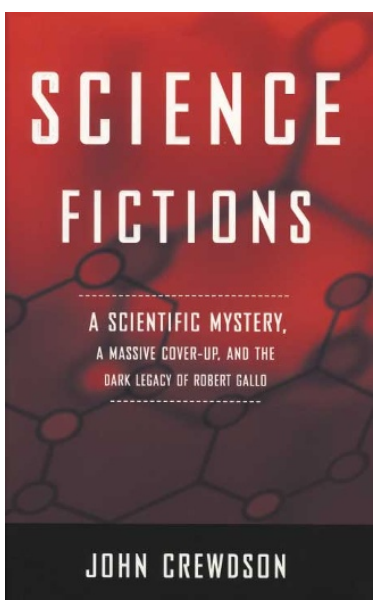
clusions from these

demiology data from Montagnier's lab were rather poor and still implicitly suggest that this early work should have had greater impact. More recently, both Montagnier and Gallo have had modest output, despite large laboratory budgets. Here again, Crewdson seems to find greater fault with Gallo.

Gallo clearly went too far in staking his claim for the discovery of the AIDS virus, but in his aversion to Gallo, Crewdson seems affected by a romantic longing for the 'old science'-the purely altruistic activity that we scientists very much want to believe academic science once was. One may not like Gallo's opportunistic, intuitive style of research, but it is increasingly common in today's biomedical community. Even when big money is not involved, modern science has become a mixture of academics, politics and business with stiff competition as the driving force. Indeed, doing science is not simply applying a 'scientific who examined the laboratory notebooks of Mika Popovic and other collaborators of Gallo and compared them with formal scientific publications, claims and patents.

From the opening statement Crewdson establishes that his book "is not about AIDS, nor is it really about science," but "about how scientists behave when the stakes are high." The book depicts the striking differences between Gallo and Montagnier with respect to their research styles-a comparison that is extrapolated to the more extroverted US and in general still more introverted European research styles. Crewdson is not only highly critical of Gallo's opportunistic and confrontational style and how he used his contacts with the popular press and editors of Science and Nature, but also of his personality. At times he is simply unfair to Gallo the scientist; for instance, when blaming him for specificity problems with the first generation of commercial US blood tests and for being wrong on some purely scientific issues. On the other hand, Crewdson is often too uncritical of Montagnier's group. It is illogical to conclude that the scientific quality and presentation of the 1983-1984 virological and sero-epi- method'. Pasteur was a great scientist, Geison concluded, in part because he was an excellent researcher in the laboratory, but mostly because he was also gifted with social skills and personal qualities that enabled him to 'Pasteurize' France. Because of this aspect of Pasteur's character, his science had an immediate impact on the daily practice of hygienists in Western Europe. Had Luc Montagnier or even Françoise Barre been a bit more 'Pasteurian', the history of the discovery of the AIDS virus might well have been rather different.

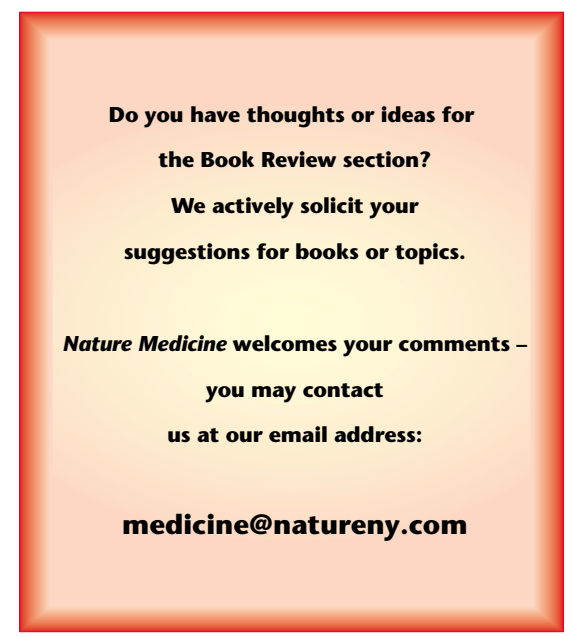

